Journal of Biotechnology and Strategic Health Research

Derleme / Review

http://dergipark.org.tr/tr/pub/bshr

\title{
Erişkin Yaş Grubunda COVID-19 Klinik Bulguları
}

\author{
Clinical Findings of The COVID-19 in the Adult Group
}

(iD) Banu Karaca

İzmir Katip Çelebi Üniversitesi Tıp Fakültesi Enfeksiyon Hastalıkları Ana Bilim Dalı

ORCID ID: Banu Karaca 0000-0003-1470-356X

^Sorumlu Yazar / Corresponding Author: Banu Karaca, e-posta / e-mail: banu.karaca@ikcu.edu.tr

Geliş Tarihi / Received : 21-04-2020 Kabul Tarihi / Accepted: 25-04-2020 Yayın Tarihi / Online Published: 30-04-2020

Atıf Gösterimi/How to Cite: Karaca B. Erişkin Yaş Grubunda COVID-19 Klinik Bulguları, J Biotechnol and Strategic Health Res. 2020;1(Özel Say1):85-90

Öz

Yeni tip Korona virus enfeksiyonun erişkin yaş grubunda klinik bulguları değişkenlik göstermekle birlikte en sık semptomlar ateş, kuru öksürük ve nefes darlığıdır. Bunlara boğaz ağrısı, myalji, başağrısı ve halsizlik eşlik edebilir. Daha nadir olarak anozmi, tat kaybının yanısıra bulantı, ishal gibi gastrointestinal semptomlar da saptanabilir. İleri yaş ve eşlik eden komorbid hastalıkların varlığı klinik tablonun ağırlaşmasında rol oynar. Klinik ARDS’ye ilerleyebilir. Olası ve kesin olgu tanımlarında laboratuvar ve radyolojik verilerin yanında klinik bulgular önem taşır.

Anahtar Covid-19, klinik, semptom.

Kelimeler

Abstract
The new Coronavirus infection has various clinical symptoms in adult age group, the most symptoms are fever, dry cough and shortness of
breath. Also sore throat, myalgia, headache and fatigue can be seen. Anosmia, loss of taste and gastrointestinal disorders such as dizziness and
diarrhea can be detected. Old age and comorbidity factors worsen disease outcome. The symptoms can progress to ARDS. To diagnose possible
and confirmed cases, clinical features are important as laboratory and radiological findings.

Keywords Covid-19, clinical, symptom. 


\section{GIIRIș}

Koronavirüsler insan ve hayvanda üst ve alt solunum yollarını tutarak hastalık oluşturan virüslerdir. İnsan Koronavirüsleri erişkin yaş grubu üst solunum yolu enfeksiyonlarının \%5-10’una neden olurken bu oran tek suş için salgın durumunda \%20-25’e çıkmaktadır. İleri yaş grubunda ise influenza benzeri hastalığın yanısıra kronik bronşit alevlenmesi ve pnömoniye neden olmaktadırlar.

Yeni tip Koronavirüs olarak bilinen aynı zamanda SARSCoV-2 ve COVID-19 olarak isimlendirilen hastalığının inkübasyon süresi 14 gün olarak bilinmektedir, genellikle temas sonrası bulgular 2-5 gün içinde gözlenmektedir. ${ }^{1,3}$ Çin'de yapılan bir çalışmada 1099 COVID-19 pozitif olguda bu süre ortalama 4 gün olarak belirtilmekte iken, bir diğer çalışmada ise enfekte olan hastaların \%97.5'inde semptomlar 11.5 . günde ve $\% 2.5$ 'inde ise 2.2 . günlerde geliştiği bildirilmektedir. ${ }^{4}$

Hastalığın klinik spektrumuna bakıldığında asemptomatik formun yanısıra, mekanik ventilasyon gerektiren respiratuar yetmezlik, sepsis, septik şok, multiorgan yetmezliğine giden tablolar görülebilmektedir. Hastalığın izlediği klinik tablonun ciddiyeti ile ilgili yine Çin Hastalık Önleme ve Kontrol Merkezinin hazırladığı raporda doğrulanmış 44.500 olgunun ciddiyet dereceleri incelenmiş ve \%81 oranında pnömoni saptanmamış veya hafif pnömoni saptanmış, \%14 oranında ciddi hastalık (dispne, hipoksi, 24-48 saat içinde \%50'den fazla akciğer tutulumu, solunum sayıs $1 \geq 30 / \mathrm{dk}$, oksijen saturasyonu $\leq 93 \%$ gibi bulgular), $\% 5$ olguda ise kritik hastalık (solunum yetmezliği, şok veya multiorgan yetmezliği) bildirilmiş.

Hafif olgularda hastalar genellikle üst solunum yolu enfeksiyonu bulguları ile başvurmakta olup bunlar arasında hafif ateş, kuru öksürük, boğaz ağrısı, nazal konjesyon, halsizlik, başağrısı, myalji bulunabilir. Hafif pnömoni varlığında öksürük ve nefes darlığı görülebilir. Ciddi hastalık varlığında dispne yoktur, ishal saptanabilir.
SARS-CoV ve MERS-CoV enfeksiyonları ile karşılaştırıldığında COVID-19 enfeksiyonunda hedef hücrelerin alt solunum yolunda olduklarını destekler şekilde rinore, hapşırma ve boğaz ağrısı gibi üst solunum yolu semptomları daha nadirdir, aynı zamanda yine SARS-CoV ve MERS-CoV enfeksiyonlarında diyare gibi gastrointestinal semptomlar \%20-25 oranında görülmekteyken COVID-19 hastalarında daha az sıklıktadır. ${ }^{5}$

Ciddi olgularda ateş, dispne, solunum sıkıntısı, takipne ve hipoksi gelişir. Ateş bazen değişkenlik gösterebilir, ciddi formda dahi görülmeyebilir, iyi değerlendirme yapılmalıdır. Bu aşamada tanıda klinik bulgular önemlidir, radyolojik değerlendirme tanıyı destekler ve komplikasyonları dışlamak için kullanılır.

Klinik tabloları özetleyecek olursak;

1. Hafif seyirli: Ateş, boğaz ağrısı, öksürük, myalji gibi semptomların olduğu, akciğer tutulumunun olmadığı tablo.

2. Hafif/orta pnömoni: Öksürük ve nefes darlığının eşlik ettiği ancak ciddi pnömoni bulgularının bulunmadığı durumlardır. Akciğer tutulumu $<\% 50$ ve oda havasında oksijen saturasyonu $>\% 90$ olan olgular.

3. Ciddi pnömoni: Ateş, solunum sıkıntısı, taşipne (>30/ $\mathrm{dk})$ ve hipoksi $(\mathrm{SpO} 2<\% 90)$ olan olgular. Ciddi olgularda ateş hafif olabilir veya hiç saptanmayabilir. Tanı klinik olarak konulur, radyoloji komplikasyonları dışlamada kullanılır.

2 tabloda incelenebilir:

1. Akciğer tutulumu BTde $>\% 50$, takipte oksijen saturasyonunun <\%90 düştügü ve oksijen desteği ile düzelme görüldüğü tablo

2. Akciğer tutulumunun hızlı ilerlediği $\mathrm{PaO} 2$ 'nin $<70$ mmHg olup, entubasyon gereken, sepsis, şok, çoklu organ yetmezliği ya da ARDS tanımlarından birisinin görüldüğü tablolar. 
ARDS tanısında klinik ve ventilasyon kriterleri önem taşır. Bu sendromda yeni gelişen respiratuar yetmezlik veya progresyon görülür. ARDS hipoksi derecesine göre hafif, orta ve ciddi ARDS olarak sinıflandirılır. Kullanılan referans parametre $\mathrm{PaO} 2$ (oksijen parsiyel basinc1) / FiO2 (inspire edilen oksijen fraksiyonu) dur. Hafif ARDS 200 $\mathrm{mmHg}<\mathrm{PaO} 2 / \mathrm{FiO}_{2}<300 \mathrm{mmHg}$, ventile olmayan ya da PEEP veya CPAP $\geq 5 \mathrm{cmH} 2 \mathrm{O}$ kullanılarak non invaziv ventilasyon yapılan durumlardır. Orta şiddette ARDS de $100 \mathrm{mmHg}<\mathrm{PaO} 2 / \mathrm{FiO} 2 \leq 200 \mathrm{mmHg}$ ve ciddi ARDS de ise $\mathrm{PaO} 2 / \mathrm{FiO} 2 \leq 100 \mathrm{mmHg}$ olarak bildirilmektedir. $\mathrm{PaO} 2$ ölçülemediği durumlarda SpO2/FiO2 $\leq 315$ oranı ARDS’yi göstermektedir.

Uluslararası sepsis ve septik şok konsensus tanımlamalarına göre sepsis, olası veya doğrulanmış enfeksiyona karşı düzenli olmayan konak yanıtının neden olduğu hayatı tehdit eden multiorgan disfonksiyonlarıdır. Sepsis gelişen COVID-19 hastalık kliniği ağır seyirlidir ve multiorgan tutulumu gözlenir. Bu tabloda ciddi dispne ve hipoksemi gibi respiratuar semptomlar, idrar çıkışının azalması ve böbrek yetmezliği, taşikardi, mental durum değişikliği, hiperbilüribinemi, asidoz, yüksek laktat düzeyleri, koagülopati ve trombositopeni gözlenebilir. Multiorgan hasarı ve prognoz belirlemede SOFA skoru kullanılır, bu skor laboratuar sonuçları ve klinik verilere göre yoğun bakım mortalitesini öngörmekte fayda sağlar. ${ }^{6}$

Mortalite oranı incelendiğinde ise bu oran genel olarak \%2.3 olarak saptanırken, kritik olmayan olgularda mortalite kaydedilmediği bildirilmiştir. Dünya Sağlık Örgütü ve Çin ortak verilerinde Wuhan'da mortalite oranını \%5.8, Çin'in diğer bölgelerinde ise $\% 0.7$ olarak bildirmektedir. ${ }^{7}$ Ölümlerin çoğu ileri yaşta ve komorbid faktörlere sahip olan olgularda görülmektedir.

Ciddi seyir ve mortalite bölgesel olarak farklılık göstermekte olup İtalya örneğinde tüm COVID-19 olgularının \%12'si ve hastaneye yatırılan olguların \%16'sı yoğun bakım ünitelerinde izlenmiştir. Mart ayı verilerinde mortalite hızı
\%7.2 olarak bildirilmiştir. ${ }^{8,9}$ Buna karşın Kore olgularında ölüm oranlarını \%0.9 olarak görmekteyiz.10 İtalya olgularında ortalama yaş 64 olarak verilirken Kore'de bu veri 40 yaştır.

Hastalık şiddeti ve zaman eğrisi Tablo-1 de verilmiştir.

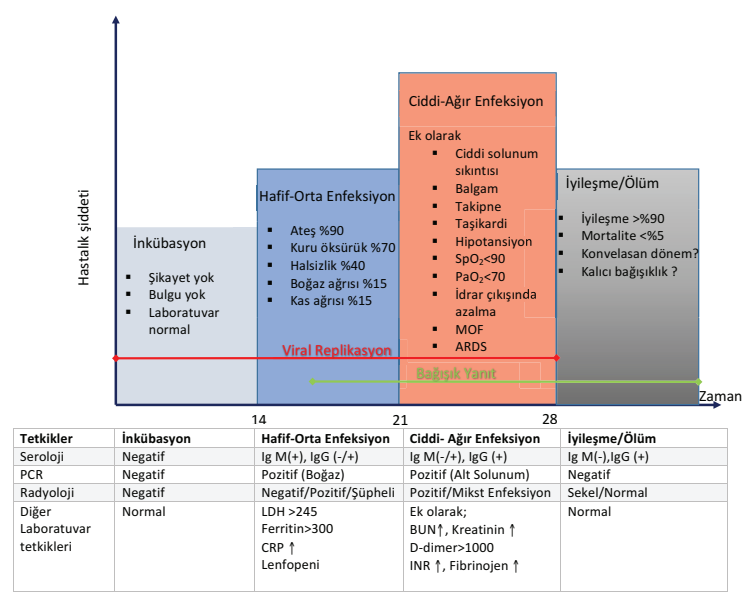

Hastalık her yaş grubunda görülebilmekte olup ileri yaş ve komorbid faktörlere sahip olan bireylerde sıklık artar. Ciddi hastalık ve mortalite ile ilişkili komorbid faktörler arasında kardiyovasküler hastalık, diyabet, hipertansiyon, kronik akciğer hastalığı, kanser, kronik böbrek hastalığ1 sayılabilir. Amerika Hastalıkları Kontrol ve Önleme Merkezi (CDC) bunlara ek olarak ciddi obesite ve karaciğer hastalıklarını da bu kriterlere eklemektedir. İtalyada ölen 355 hastada ortalama komorbid hastalık sayısını \%2.7 olarak bildirilmiştir, 3 hastada ise komorbid faktöre rastlanmamıştır. Washington'da bakımevlerinde yapılan araştırmada 101 kişinin ortalama yaşları 83 olarak bildirilmiş bu hastaların \%94' ünde altta yatan kronik hastalık bildirilmektedir, hastaneye yatış oranı \%55 ve mortalite $\% 34$ olarak saptanmıştır. ${ }^{11}$

Erkek cinsiyette ölüm oranları Çin ve İtalya çalışmalarında daha yüksek olarak bildirilmektedir., ${ }^{9}$

Laboratuvar bulgularından kötü prognoz kriterleri ise lenfopeni, karaciğer enzim yükseklikleri, laktat dehidrogenaz yüksekliği, inflamatuvar markerlarda yükseklik (CRP, fer- 
ritin vb) D dimer yüksekliği (>1mcg/ml), uzamış protrombin zamanı, troponin yüksekliği, kreatin fosfokinaz yüksekliği, akut böbrek hasarıdır. Bunun yanında respiratuvar örneklerde yüksek viral RNA saptanan olgularda klinik daha ağır seyirli olarak karşımıza çıkmaktadır. ${ }^{13}$

Hastaneye yatırılan hastaların yaşlarına bakıldı̆̆ında 4956 arasında değişmektedir, Çin Hastalıkları Kontrol ve Önleme Merkezi verilerine göre 44500 doğrulanmış olguda 70-79 yaş aralığında mortalite \%8 iken bu oran 80 yaş üzerinde \%15’e yükselmektedir. Bu verilerde tüm kohortun mortalite oranı ise \% 2.3 olarak bildirilmektedir. ${ }^{14}$ İtalya verilerinde de benzer şekilde $70-79$ yaş ve 80 yaş ve üzeri gruplarda sirasılyla mortalite oranları \%12 ve \%20 olarak verilmektedir. ${ }^{9}$

Asemptomatik enfeksiyon tanımlanmaktadır ancak sıklık bilinmemektedir. Bir seyir gemisinde salgın sırasında yapılan tüm yolcu ve personelde taramada yaklaşı \%17 pozitiflik saptanmış ve 619 doğrulanan olgunun yarısı asemptomatik olarak bildirilmiştir. ${ }^{15}$ Asemptomatik 24 olguda yapılan akciğer tomografilerinin \%50' sinde tipik buzlu cam ve yamasal tutulum saptanırken \%20'sinde ise atipik bulgular saptanmıştır. ${ }^{16} \mathrm{Bu}$ hastaların 5'inde tanıyı takip eden günlerde hafif ateş, buna eşlik eden veya etmeyen tipik bulgular saptandığı bildirilmektedir.

Hastaların kliniklere geliş yakınmalarına bakacak olursak Wuhan'da 138 pnömonili hastada yapılan bir çalışmada en sık bulgular ateş $\% 99$, halsizlik \%70, kuru öksürük \%59, iştahsızlık \%40, myalji \%35, dispne \%31, balgam çıkarma \%27 oranında bildirilmektedir. Ateş genellikle saptanmasına karşın yine Wuhan'da yapılan bir çalışmada \%20 olguda 38 derecenin altında saptanmış ve yine Çin'de 1099 olguda \%44 oranında hastalığın başlangıç döneminde ateş saptandığı bu oranın hastaneye yatış döneminde \%89’a yükseldiği bildirilmektedir. ${ }^{17}$ Ayrıca koku ve tat duyusu bozuklukları ayırdedici olmamakla beraber bildirilen semptomlar arasında yerini alır. ${ }^{18}$ Daha nadir semptomlar arasında başağrısı, boğaz ağrısı ve burun akıntısı gelmek- tedir. Respiratuar semptomların yanında bulantı, ishal gibi gastrointestinal semptomların da ilk başvuru semptomu olarak karşımıza çıkabileceği akılda tutulmalıdır.

Başlangıç semptomları hafif seyreden bazı olgular 1 hafta süre içinde progresyon gösterebilir. Wuhan'da pnömonisi olan 138 hastada semptomların başlangıcından ortalama 5 gün sonra dispne geliştiği ve semptomların 7. gününde hastaneye yatırıldığı bildirilmektedir. Dispneden kısa bir süre sonra gelişen ARDS ciddi hastalığı olan olgularda görülen major komplikasyondur. Yukarıda anlatılan çalışmada ARDS semptomların başlangıcından ortalama 8 . günde $\% 20$ oranında saptanmıștır ve mekanik ventilasyon ihtiyacı \% 12.3 olarak bildirilmiştir. ARDS 65 yaş üzerinde, diyabet ve hipertansiyon gibi hastalığı olan olgularda daha sık görülmektedir.

Diğer komplikasyonlar aritmi, akut kardiyak hasar ve şoktur. Yapılan çalışmalarda oranlar sırasıyla \%17, \%7 ve \%9 olarak bildirilmektedir. Amerika'da yoğun bakım ünitesinde yapılan bir çalışmada 21 hastanın üçte birinde kardiyomyopati geliştiği bildirilmektedir. ${ }^{19}$

Ciddi olgularda sitokin firtınasına benzerlik gösteren yaygın inflamatuar yanıtın bulguları olan persistan ateş, D dimer ve ferritin gibi inflamatuar markerlarda yükseklik ve proinflamatuar sitokinlerde artış mortalite ile ilişkili bulunmaktadir.

Dünya Sağlık Örgütü iyileşme süresini hafif olgularda 2 hafta, ciddi olgularda ise 3-6 hafta olarak bildirmektedir. ${ }^{20}$ Semptomatik COVID-19 hastalarında epidemiyolojik temas sorgulanması olası ve doğrulanmış olgu tanısında gereklidir ancak pandemi durumunda hastalığın toplumda yaygın görülmesi nedeni ile önemini klinik bulgulara birakmaktadır.

Viral atılımın dalgalanma ile seyretmesi, ilk 4-5 gün üst solunum yolları ardından alt solunum yolları materyallerinde virus saptanabilmesi ve örnek alım tekniğinde yapı- 
lan hatalar nedeni ile, altın standart olan PCR yönteminde zaman zaman sıkıntılar yaşanabilmekte ve hızlı antikor testleri 7-10 günde daha anlamlı olması aynı zamanda henüz yaygın kullanılamaması nedeni ile tanıda klinik bulgular ve radyolojik bulgular önemlidir. 
J Biotechnol and Strategic Health Res. 2020;1(Özel Sayı):85-90

KARACA, Erişkinlerde COVID-19 Klinik Bulguları

\section{Kaynaklar}

1. Li Q, Guan X, Wu P, et al. Early Transmission Dynamics in Wuhan, China, of Novel Coronavirus Infected Pneumonia. N Engl J Med 2020; 382:1199.

2. Guan WJ, Ni ZY, Hu Y, et al. Clinical Characteristics of Coronavirus Disease 2019 in China. N Engl J Med 2020.

3. Chan JF, Yuan S, Kok KH, et al. A familial cluster of pneumonia associated with the 2019 novel coronavirus indicating person-to-person transmission: a study of a family cluster. Lancet 2020; 395:514.

4. Lauer SA, Grantz KH, Bi Q, et al. The Incubation Period of Coronavirus Disease 2019 (COVID-19) From Publicly Reported Confirmed Cases: Estimation and Application. Ann Intern Med 2020.

5. Chaolin Huang, Yeming Wang, Xingwang Li, et al. Clinical features of patients infected with 2019 novel coronavirus in Wuhan, China. Lancet 2020; 395: 497-506 Published Online January 24, 2020

6. Cascella M, Rajnik M, Cuomo A, et al. Features, Evaluation and Treatment Coronavirus (COVID-19). Stat Pearls [Internet]. Treasure Island (FL): Stat Pearls Publishing; 2020. Mar 20.

7. Report of the WHO-China Joint Mission on Coronavirus DIsease 2019 (COVID-2019). February 16-24, 2020. http://www.who.int/docs/default-source/coronaviruse/who-china-joint-mission-on-covid-19-final-report.pdf (Accessed on March 04, 2020).

8. Grasselli G, Pesenti A, Cecconi M. Critical Care Utilization for the COVID-19 Outbreak in Lombardy, Italy: Early Experience and Forecast During an Emergency Response. JAMA. 2020.

9. Onder G, Rezza G, Brusaferro S. Case-Fatality Rate and Characteristics of Patients Dying in Relation to COVID-19 in Italy. JAMA 2020.

10. KCDC. Updates on COVID-19 in Korea. March 14, 2020. https://www.cdc.go.kr/board/ board.esmid $=a 30402000000 \mathrm{\&}$ bid $=0030$ (Accessed on March 14, 2020).
11. Mc Michael TM, Currie DW, Clark S, et al. Epidemiology of Covid-19 in a Long-Term Care Facility in King County, Washington. N Engl J Med 2020.

12. Chen T, Wu D, Chen H, et al. Clinical characteristics of 113 deceased patients with coronavirus disease 2019: retrospective study. BMJ 2020; 368:m1091.

13. Liu Y, Yan LM, Wan L, et al. Viral dynamics in mild and severe cases of COVID-19. Lancet Infect Dis 2020.

14. Wu Z, McGoogan JM. Characteristics of and Important Lessons From the Coronavirus Disease 2019 (COVID-19) Outbreak in China: Summary of a Report of 72314 Cases From the Chinese Center for Disease Control and Prevention. JAMA 2020.

15. Japanese National Institute of Infectious Diseases. Field Briefing: Diamond Princess CO VID-19 Cases, 20 Feb Update. https://www.niid.go.jp/niid/en/2019-ncov-e/9417-covid-dpfe-02.html (Accessed on March 01, 2020).

16. $\mathrm{Hu} \mathrm{Z}$, Song $\mathrm{C}, \mathrm{Xu} \mathrm{C}$, et al. Clinical characteristics of 24 asymptomatic infections with $\mathrm{CO}$ VID-19 screened among close contacts in Nanjing, China. Sci China Life Sci 2020.

17. Guan WJ, Ni ZY, Hu Y, et al. Clinical Characteristics of Coronavirus Disease 2019 in China. N Engl J Med 2020.

18. Giacomelli A, Pezzati L, Conti F, et al. Self-reported olfactory and taste disorders in SARSCoV-2 patients: a cross-sectional study. Clin Infect Dis 2020.

19. Arentz M, Yim E, Klaff L, et al. Characteristics and Outcomes of 21 Critically Ill Patients With COVID-19 in Washington State. JAMA 2020.

20. World Health Organization Director-General's opening remarks at the media briefing on COVID-19 - 24 February 2020 https://www.who.int/dg/speeches/detail/who-director-general-s-opening-remarks-at-the-media-briefing-on-covid-19-24-february-2020 (Accessed on February 26, 2020). 